\title{
Potentialities of Agricultural Development for Some Soil Along Aswan-Toshka District
}

\author{
Abdalsamad A. A. Aldabaa ${ }^{1}$, Asmaa Abdu Shata ${ }^{1}$, and Mohamed Y. Draz ${ }^{1}$
}

\begin{abstract}
The proficient management of the available natural resources of Egypt is necessary in order to save food demands of the rapidly increasing population. In the processing of land use planning, estimating the agricultural land potentiality is important footstep where the agricultural resources are so limited. Toshka spillway area is one of the greatest promising area for horizontal agricultural extension where the fresh water is available. The main goal of the current study is to produce land priority map based on different thematic layers of some soil parameters that affect on or control the agricultural potentiality by designing a suitable GIS-based model for data integration with relevant logical condition of the area along Aswan Toshka District, south of Egypt. The parameters taken into consideration were slope, soil texture, soil depth, gravel content, calcium carbonate, soil salinity, and soil reaction. By using GIS environment, these parameters were interpolated in order to recognize their spatial variability by differentiating each property as sever, moderate, slight, and no limitations. Accordingly, The analysis showed that the soil depth, soil gravel, and soil reaction were the major limitation factors comparing with the other soil factors. The priority of Land Suitability Potential Index (LSPI) for Agricultural purpose was calculated by the contribution of the abovementioned parameters. The potentiality was categorized as not suitable, marginally suitable, moderately suitable, and highly suitable. These classes were attained by integrating the different thematic layers with corresponding weights in geographical information system (GIS). The output of study indicated that the study area can be mainly described as moderately suitable where it covers about $81.04 \%$ of the total area, while highly suitable, marginal suitable and not suitable attained the lower converge 9.23, 9.01, and $0.72 \%$, respectively. The study concluded that any given area can be categorized into spatially distributed agricultural potential zones based on the soil characteristics and terrain properties by the profound assist of geographical information system (GIS).
\end{abstract}

Key words: Potentialities, Agricultural development, Toshka, GIS, Suitability index

\section{INTRODUCTION}

Land resources in Egypt face pressures from continuing land degradation as well as increase of population. The population in Egypt is increasing very rapidly and its intensity has been twofold during the last decades, (Hamza and Mason, 2004). Accordingly, the proficient management of the natural resources of Egypt is necessary for ensuring food supply and sustainability in agricultural development (El Baroudy, 2016). In the process of land use planning, land evaluation is an important footstep where resources (land, water and fund) are so limited especially in Egypt. In order to manage these resources in proper way, land suitability assessment is always conducted to assess which part of land is almost suitable or fit to a specific location (Bodaghabadi et al., 2015). Land suitability evaluation process tend to recognize the main limiting factors of a particular crop yield for given area (Halder, 2013), where the requirements of land use are significantly met by the properties of the given land. Hence, the main object of land suitability potential evaluation is to predict the inherited land capability so as to support the land use specifically for long time without any hazard of damage. Moreover, it enables decision makers to put an efficient way to develop a crop management for increasing land productivity to meet the increase of human demands (Chen, 2014). In arid and semiarid region as Egypt, the availability of water and soil fertility status as well as other soil qualities limit crop productivity (Kerr et al., 2002) and (Rockström et al., 2003). Such these areas are characterized high evaporation rate as result of the high temperature which accordingly accelerates the decomposition rate of organic matter. Like this situation, the sustained land use planning, therefore, includes the decision of land use so that the available resources are put into use according to the determined potentiality (Rockström et al., 2002). Various approaches of land evaluation have been developed, and each has a specific methodological procedure (Brink and Young, 1977; De la Rosa et al., 2004; O'Geen, 2008; Hamad, 2016). The land evaluation systems are either qualitative, quantitative, or both. The qualitative ones are empirical assessment depending on the knowledge and the understanding of the study area. On the other hand, the quantitative ones are a factor-based land evaluation systems and involve more detailed land attributes by using parametric techniques that use either single or multiple parameters converted to an integrated index (Guo et al., 2005). The Food and Agricultural Organization (FAO) suggested an approach for land suitability evaluation for crops in terms of suitability ratings varying from highly suitable

\footnotetext{
${ }^{1}$ Desert Research Center

Corresponding author: (abdelstar2004@gmail.com)

Received OCTOBR 11, 2018, Accepted November 12, 2018
} 
to not suitable based on terrain data and soil properties in addition to climatic data (Brink and Young, 1977). Sys and Verheye (1972) recommended a capability index, depending on various parameters, related to soil properties and, subsequently, an extent of capability indexes were proposed to designate soil limitations for crop production. With advances in information and communication technology, computer based decision support models have been developed towards land evaluation (De la Rosa et al., 1992) and (Yen et al., 2006).

Recently the geographical information system (GIS) and remote sensing (RS) have been applied to accomplish land evaluation through map analysis techniques (Kalogirou, 2002) and (Baja et al., 2002). In addition, they provide a great promises for improving the convenience and accuracy of spatial data to be more productive assessment and enhance data access (El Baroudy, 2016). These techniques have been applied and used to determine the properties desired to define the land suitability (De la Rosa and Van Diepen, 2002), (Mokarram et al., 2010), and (Hamzeh et al., 2014).

Under the effort of Egyptian government for the horizontal and vertical agricultural expansion, the current study aim at providing a database of arable land in desert areas. In agricultural point of view, it should evaluate the productive potentiality of given land before using to assess the suitability areas. To attain that purpose, the main objectives of this research are: (i) to produce different thematic maps of some soil properties that affect on or control the agricultural potential through the conventional methods of soil survey, (ii) to categorize the thematic features based on their merit and demerit with respect to agricultural land potential, (iii) to design a suitable GIS-based model for data integration with relevant logical condition, and (iv) to prepare land priority map expressed by Land Suitability Potential Index (LSPI) through evaluating the limiting soil factors of the area along Aswan Toshka District.

\section{MATERIALS AND METHODS}

\section{General occurrence and feature of the study area}

The study area is located in the southern Egypt near Toshka lake. It lies between $22^{\circ} 54^{\prime} 06^{\prime \prime}$ to $23^{\circ} 14^{\prime} 29^{\prime \prime} \mathrm{N}$ and $31^{\circ} 37^{\prime} 04^{\prime \prime}$ to $32^{\circ} 00^{\prime} 18^{\prime \prime} \mathrm{E}$, occupying an area of about $618 \mathrm{~km}^{2}$ (148320 faddan), Fig (1). It is located some $250 \mathrm{~km}$ to the southwest away from Aswan City and some of $50 \mathrm{~km}$ from Abu Simble City. As for the climatic data, shown in Table (1) and Fig (2), the annual precipitation is lower than $1 \mathrm{~mm} /$ year. The average temperature ranges 9.2 to $25.3{ }^{\circ} \mathrm{C}$ in winter and from 42.3 to $44.1{ }^{\circ} \mathrm{C}$ in summer. The relative humidity recorded as average is fluctuating between 14 and $38 \%$. The average wind speed varies from 2.3 to $3.1 \mathrm{~m} / \mathrm{sec}$. the study area is under hyperarid condition as indicated by the aridity index, being less than 0.05 , (Middleton and Thomas, 1992). Geologically, the surface of this area is covered by different type of geological formation, Fig (2). According to Moneim et al. (2014), the Quaternary deposits are characterized mainly by sand sheets that covers of about 99300 faddan. Sabaya formation, representing the Lower Cretaceous, consists mainly of sandstone, ferruginous sandstone with thin bed of conglomerate. It covers an area of about 16314 faddan. Kiseiba formation covering around 30793 faddan, consists of shale and sandstone of Upper Cretaceous. The basement rocks occur as relic exposures of low relief and they consist of gneiss and magmatic gneiss that highly modified by weathering. This formation is occupies an area of about 1913 faddan.

In respect of geomorphology, the study area is considered as one geomorphic unit as mentioned by, (Moneim et al., 2014) while DRC (2014) divided the area under consideration into four main units, Figure (2). The first landform is Karstified platform which covers the southern part of the study area. This landform appears as some rock exposures of Precambrian, cretaceous and/or Tertiary era. Some parts this of unit is affected by hydrothermal solutions. It occupies an area of about 39789 faddan. The second one encompasses both Mesas and Buttes, covering about 9000 faddan, particularly at the eastern, southeastern and western portion of the study area. This landform has been formed under the effect of structure (folding). Third, is pediplain covering an area of about 22141 faddan particularly at the northeastern and north part of the study area. It is a rocky surface that is considered the final form of erosional / depositional stage. Finally, sand sheets which cover very large area of about 77390 faddan and they belong to the depositional land forms. Because of the scarcity of rainfall, these sand sheets cover the shallow wadies and its terraces and alluvial fans, Figure (3).

\section{2-Soil Sampling and Laboratory analysis}

Through implementing a project carried out by Desert Research Center (2014), (DRC, 2014), soil Samples were conducted based on a survey grid where the distance between each two consecutive sites is $1 \mathrm{~km}$, Figure (4). Accordingly, 618 soil profiles were digged and a detailed morphological description of the studied soil profiles was elaborated on the basis outlined by FAO guideline of soil profile description, (Jahn et al., 2006). A number of 1574 representative soil samples have been collected from the soil profiles and analyzed for chemical and physical properties. In the laboratory, 
all dried samples were ground to pass a $2 \mathrm{~mm}$ sieve, then subjected to standard soil characterization.

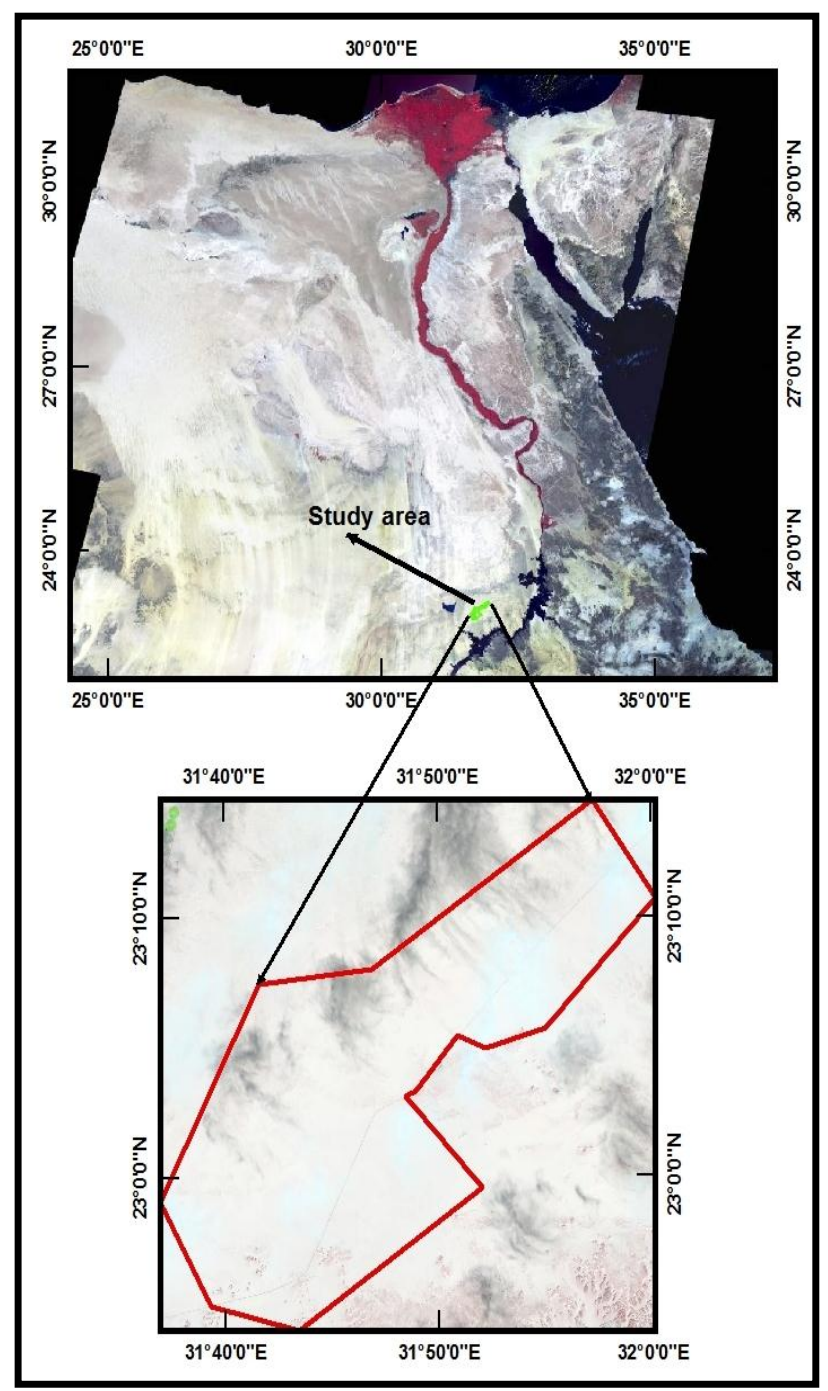

Figure 1.Location map of the study area

Table 1. Monthly average data of some climatic elements

\begin{tabular}{cccccccc}
\hline Months & \multicolumn{3}{c}{ Temperature $^{\circ} \mathbf{C}$} & Relative humidity & $\begin{array}{c}\text { Wind speed } \\
\text { m/sec }\end{array}$ & $\begin{array}{c}\text { Sunshine } \\
\text { hours }\end{array}$ & $\begin{array}{c}\text { Rainfall } \\
\text { mm }\end{array}$ \\
\cline { 2 - 7 } & Maximum & Minimum & Average & \% & 2.5 & 8.0 & 0.1 \\
Jan. & 24.6 & 9.2 & 16.9 & 37 & 2.7 & 8.5 & 0.0 \\
Feb. & 27.7 & 10.6 & 19.2 & 27 & 3.0 & 10.0 & 0.0 \\
Mar & 32.9 & 15.0 & 24.0 & 19 & 3.1 & 10.4 & 0.0 \\
Apr & 35.9 & 18.0 & 27.0 & 17 & 3.0 & 10.9 & 0.0 \\
May & 39.4 & 21.9 & 30.7 & 15 & 2.4 & 12.6 & 0.0 \\
Jun & 42.4 & 24.5 & 33.5 & 14 & 2.3 & 12.1 & 0.0 \\
Jul & 42.3 & 24.6 & 33.5 & 16 & 2.7 & 10.2 & 0.0 \\
Aug & 44.1 & 25.3 & 34.7 & 17 & 2.5 & 8.7 & 0.0 \\
Sep & 40.3 & 23.7 & 32.0 & 20 & 2.0 & 0.0 \\
Oct & 34.6 & 19.4 & 27.0 & 23 & 2.6 & 8.1 & 0.0 \\
Nov & 29.5 & 14.3 & 21.9 & 36 & 2.5 & 8.0 & 0.1 \\
Dec & 24.3 & 9.7 & 17.0 & 38 & 2.7 & & \\
\hline
\end{tabular}




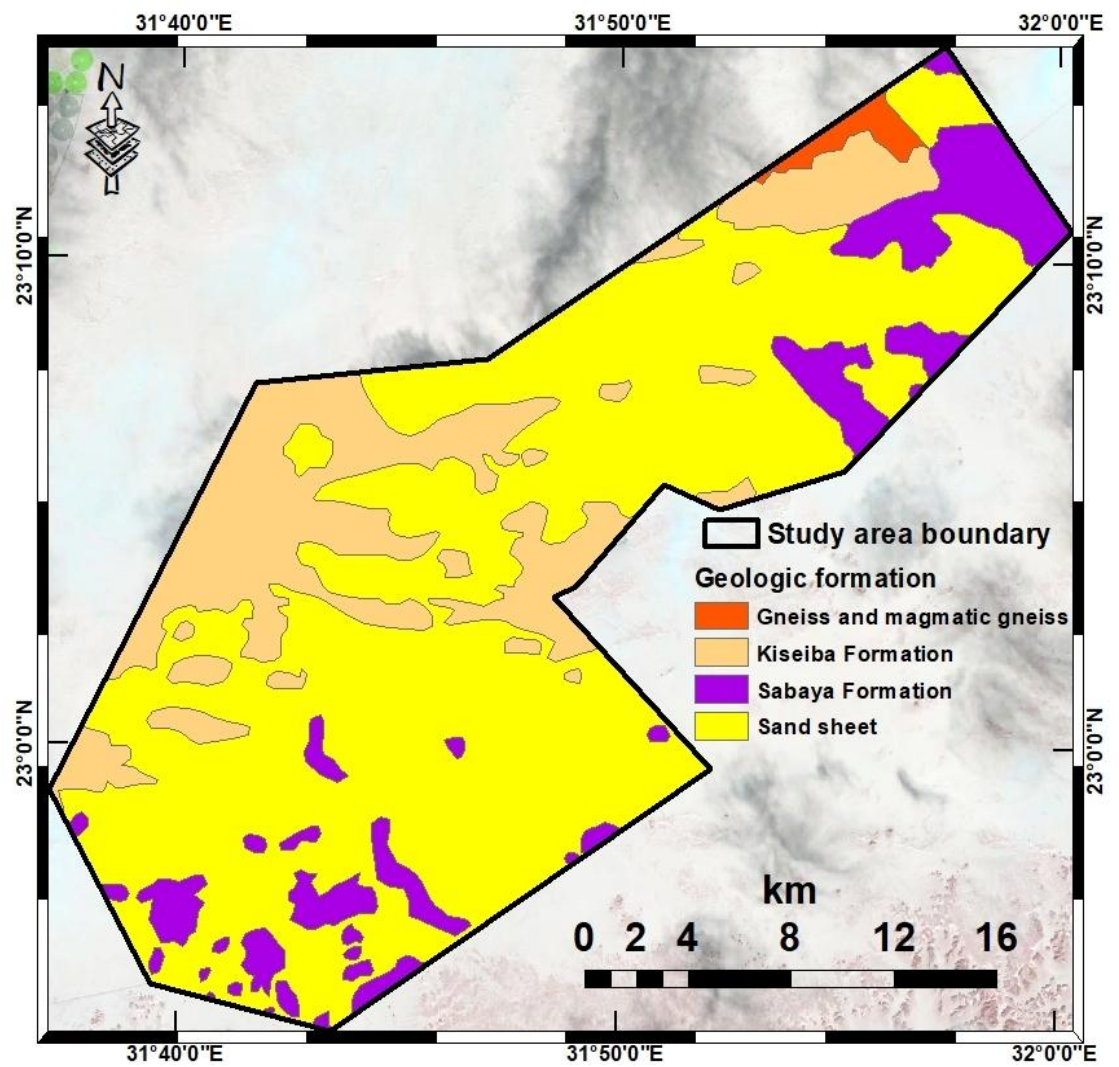

Figure 2. Surface geology of the study area, (Moneim et al., 2014).

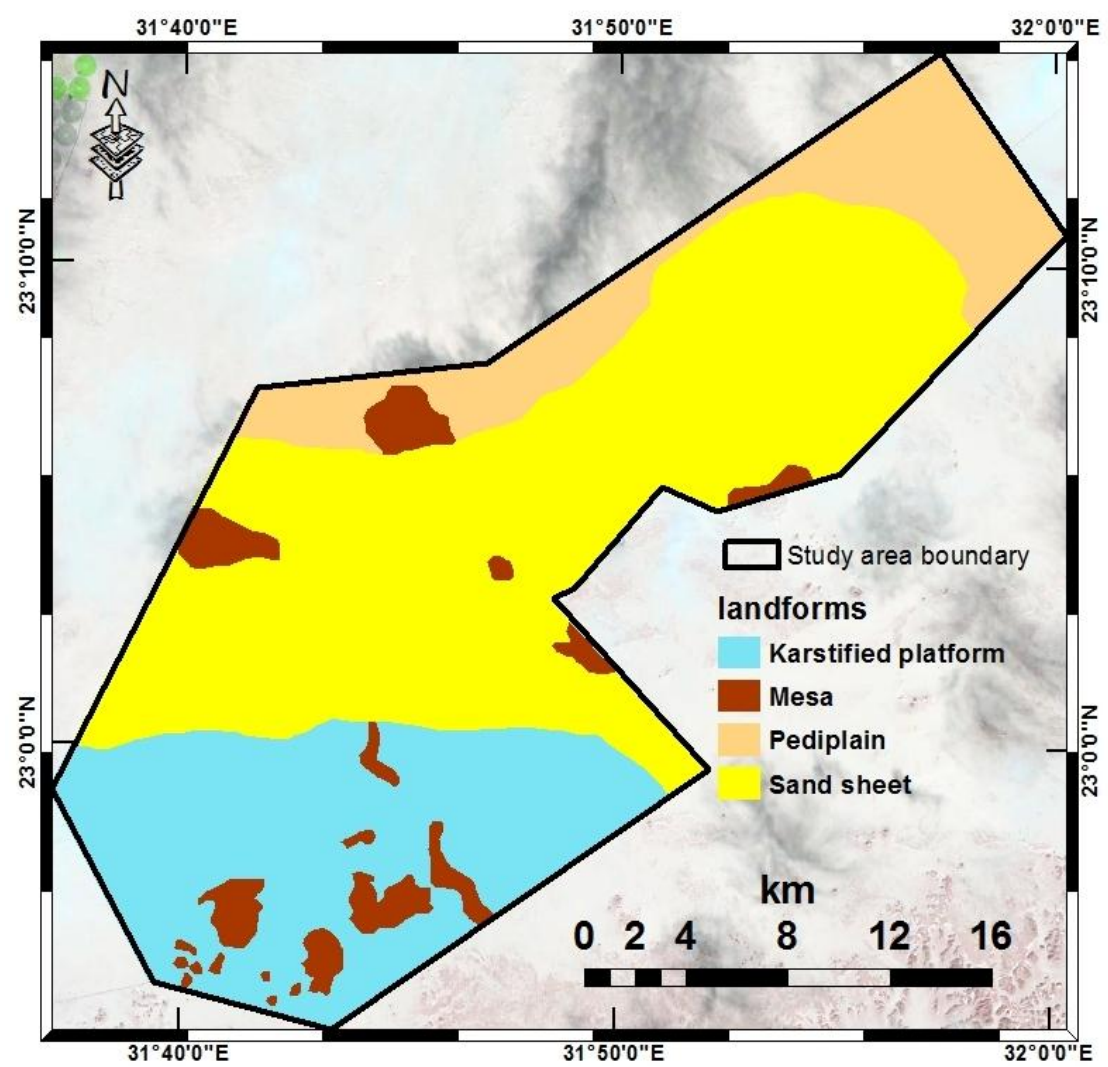

Figure 3. Landforms of the study area,(DRC, 2014). 
The gravel percentage was calculated volumetrically (USDA, 2004). Particle size analysis was accomplished via hydrometer, with silt + clay and clay readings at 40 $\mathrm{sec}$ and $360 \mathrm{~min}$, respectively, using a Model $152 \mathrm{H}$ hydrometer and the method carried out by Bouyoucos (1962). Soil pH and electrical conductivity (EC) were determined via saturated soil water extraction 1:2.5 using EC/pH conductivity meter (Sonmez et al., 2008). Calcium carbonate content was determined via a pressure calcimeter (Sherrod et al., 2002).

\section{3- Database and methodology of land suitability}

It should notify that, especially for the study area, the water quality and quantity are available due to the study area is near by the New Valley Project (Toshka spillway). In horizontal agricultural expansion projects like in Egypt, if the water quantity and quality are available, the soil depth, soil texture and slope as well as other soil properties play a vital role for that expansion. For detecting the potentiality of agricultural development at the current study area, the spatial information regarding to the selected criterion i.e. slope, soil depth, soil texture, soil salinity, soil $\mathrm{pH}$, and calcium carbonate content were used to present the suitability model. The slope as well as the elevation were derived from the digital elevation model version 3 downloaded from the USGS website https://earthexplorer.usgs.gov/. All the soil related data of each soil profile were converted to single values using the weighted mean by multiplying the parameter value of each layer by the layer thickness divided by the total depth of soil profile. Therefore the spatial variability map of each soil property were created for the study area using ArcMap 10.4.1, Topo To Raster option, spatial Analyst Tool. The obtained layer of each property was reclassified according to its limitation so (1) as sever, (2) as moderate, (3) as slight, and (4) as no limitation, Table (2).

Table 2. The limitation of soil properties and their weight for the study area

\begin{tabular}{|c|c|c|c|c|}
\hline Soil layer & Category & Reclassification number & Limitation & Layer weight \\
\hline \multirow{4}{*}{$\begin{array}{l}\text { Soil Depth (SD) } \\
\text { cm }\end{array}$} & $0-25$ & 1 & Sever & \multirow{4}{*}{0.6} \\
\hline & $25-50$ & 2 & Moderate & \\
\hline & $50-100$ & 3 & slight & \\
\hline & $100-150$ & 4 & No & \\
\hline \multirow{3}{*}{ Soil texture (ST) } & Sand & 2 & Moderate & \multirow{3}{*}{0.2} \\
\hline & Loamy sand & 3 & Slight & \\
\hline & Sandy loam & 4 & No & \\
\hline \multirow{4}{*}{$\begin{array}{c}\text { Soil Gravel (SG) } \\
\%\end{array}$} & $0-5$ & 4 & No & \multirow{4}{*}{0.15} \\
\hline & $5-15$ & 3 & Slight & \\
\hline & $15-40$ & 2 & Moderate & \\
\hline & $>40$ & 1 & Sever & \\
\hline \multirow{2}{*}{$\begin{array}{c}\text { Soil slope (SL) } \\
\% \\
\end{array}$} & $0-1$ & 4 & No & \multirow{2}{*}{0.02} \\
\hline & $1-2$ & 3 & Slight & \\
\hline \multirow{4}{*}{$\begin{array}{c}\text { Soil Carbonate (SC) } \\
\%\end{array}$} & $0-2$ & 3 & Slight & \multirow{4}{*}{0.01} \\
\hline & $2-10$ & 4 & No & \\
\hline & $10-25$ & 2 & Moderate & \\
\hline & $>25$ & 1 & Sever & \\
\hline \multirow{4}{*}{$\begin{array}{l}\text { Soil Salinity (SS) } \\
\text { dS/m }\end{array}$} & $0-2$ & 4 & No & \multirow{4}{*}{0.01} \\
\hline & $2-4$ & 3 & Slight & \\
\hline & $4-8$ & 2 & Moderate & \\
\hline & $>8$ & 1 & Sever & \\
\hline \multirow{4}{*}{ Soil Reaction (SR) } & $7.3-7.8$ & 4 & No & \multirow{4}{*}{0.01} \\
\hline & $7.8-8.4$ & 3 & Slight & \\
\hline & $8.4-9$ & 2 & Moderate & \\
\hline & $>9$ & 1 & Sever & \\
\hline
\end{tabular}


Accordingly, suitable weights were assigned to each layer according to its effect on the productivity potentiality in agricultural point of view. They, therefore, were integrated and analyzed using the weighted aggregation method, ArcMap 10.4.1, Spatial Analyst Tool, Overlay, Weighted sum. In this method, the total weights of the final integrated layer map was derived as sums of the weights assigned to different layers, according to their suitability. The final obtained map displays the prioritized areas for land use as first priority, second priority, ....etc.

The equation used in GIS to assess the Land Suitability Potential Index (LSPI) for Agricultural purpose is:

$$
\begin{aligned}
\mathrm{LSPI} & =0.6(\mathrm{SD})+0.2(\mathrm{ST})+0.15(\mathrm{SG})+0.02(\mathrm{SL}) \\
& +0.01(\mathrm{SC})+0.01(\mathrm{SS})+0.01(\mathrm{SR})
\end{aligned}
$$

The weighted value of each property was assigned by this numerical value based on the influence of each property on the use of soil under the study area circumstances. Therefore, it is found that the soil depth is the most important limiting factor of potential land use, so it was weighted by the highest value $(60 \%)$. Then it is followed by soil texture (20\%) and soil gravel $(15 \%)$, while the soil slope $(2 \%)$, calcium carbonate, soil salinity, or $\mathrm{pH}$ were weighted by the lowest weighted value $(1 \%)$ where they do not influence the Agricultural process in the study area.

\section{RERSULTS AND DISCUSSION}

\section{1- Soil mapping Units}

Due the huge data of the study area, results related to descriptive statistical data are present in the supplementary Table (3) and Figure (5). These data were summarized based on the soil mapping unit which was designed according to the soil depth and soil texture categories mentioned by Soil Survey Staff (1993). Description of gravel, salinity, and soil reaction were defined according to Schoeneberger (2002). In such manner, the soil profiles were grouped according to soil depth where depth ranges from $0-50 \mathrm{~cm}$ represent shallow, 50-100 $\mathrm{cm}$ represent moderately deep, and greater than $100 \mathrm{~cm}$ represent deep soils. As for the soil texture, the sand and loamy sand texture represent the coarse-texture and sandy loams represent the moderately coarse-texture. Both of soil depth and soil texture were spatially mapped and then reclassified as shown in Table (3). After reclassification, they mathematically combined using PLUS spatial analyst tool, ArcMap 10.4.1, to get the final mapping units. Therefore, 6 soil mapping were obtained and statistically discussed.

\section{1- Shallow coarse-textured soils (SMU01)}

This unit occupies an area of about 1820.09 faddan and could be distinguished into sand and/or loamy sand. The gravel content ranged from none to abundant (0.14 $44.94 \%)$. The surface slope of theis units ranged from 0.13 to $1.19 \%$ as flat to almost flat surface. The soils are slightly calcareous to strongly calcareous (0.31$20.78 \%$ ), non-saline to slightly saline (0.61 to 6.67) and showing neutral to moderately alkaline reaction (7.34 to 8.16). Reversely, the soil depth had the highest values of the standard deviation and standard error, while the soil $\mathrm{pH}$ and surface slope have gotten the lowest values, respectievly. Base on the mean values of the characterstics studied, this unit could be related to "Almost flat, Shallow, Gravelly coarse-textured, Strongly calcareous, Non-saline, Slightly alkaline".

\section{2- Shallow moderately coarse-textured soils (SMU02)}

The soils of this unit, occupying an area of about 30276.13 faddan is mostely in the middel part of studied area pariculary within the pediplain. soils have sandy loam texture and gravel content ranging between 0 to $29.04 \%$. The surafce slope ranges from 0.12 to $0.98 \%$ represnting flat to almost surafce. These soils are slightly calcareous to strongly calcareous where calcium

Table 3. The methodology for getting the final soil mapping units' codes

\begin{tabular}{lccc}
\hline Soil Mapping Units & \multicolumn{2}{c}{ Reclassified Code } & Combination code \\
\cline { 2 - 3 } & Soil texture & Soil depth & \\
\hline SMU01 (Shallow coarse-textured soils) & 10 & 1 & 11 \\
SMU02 (Shallow moderately coarse-textured soils) & 20 & 1 & 21 \\
SMU03 (Moderately deep coarse-textured soils) & 10 & 2 & 12 \\
SMU04 (Moderately deep moderately coarse-textured soils) & 20 & 2 & 22 \\
SMU05 (Deep coarse-textured soils) & 10 & 3 & 13 \\
SMU06 (Deep moderately coarse-textured soils) & 20 & 3 & 23 \\
\hline Where; & -Shallow: & $<50 \mathrm{~cm} \mathrm{depth}$ \\
-Coarse-Texture: Sandy and loamy sand soils & -Moderately deep: 50-100 cm depth \\
-Moderately-Texture: Sandy loam soils. & -Deep: & $100-150 \mathrm{~cm}$ depth \\
\hline
\end{tabular}




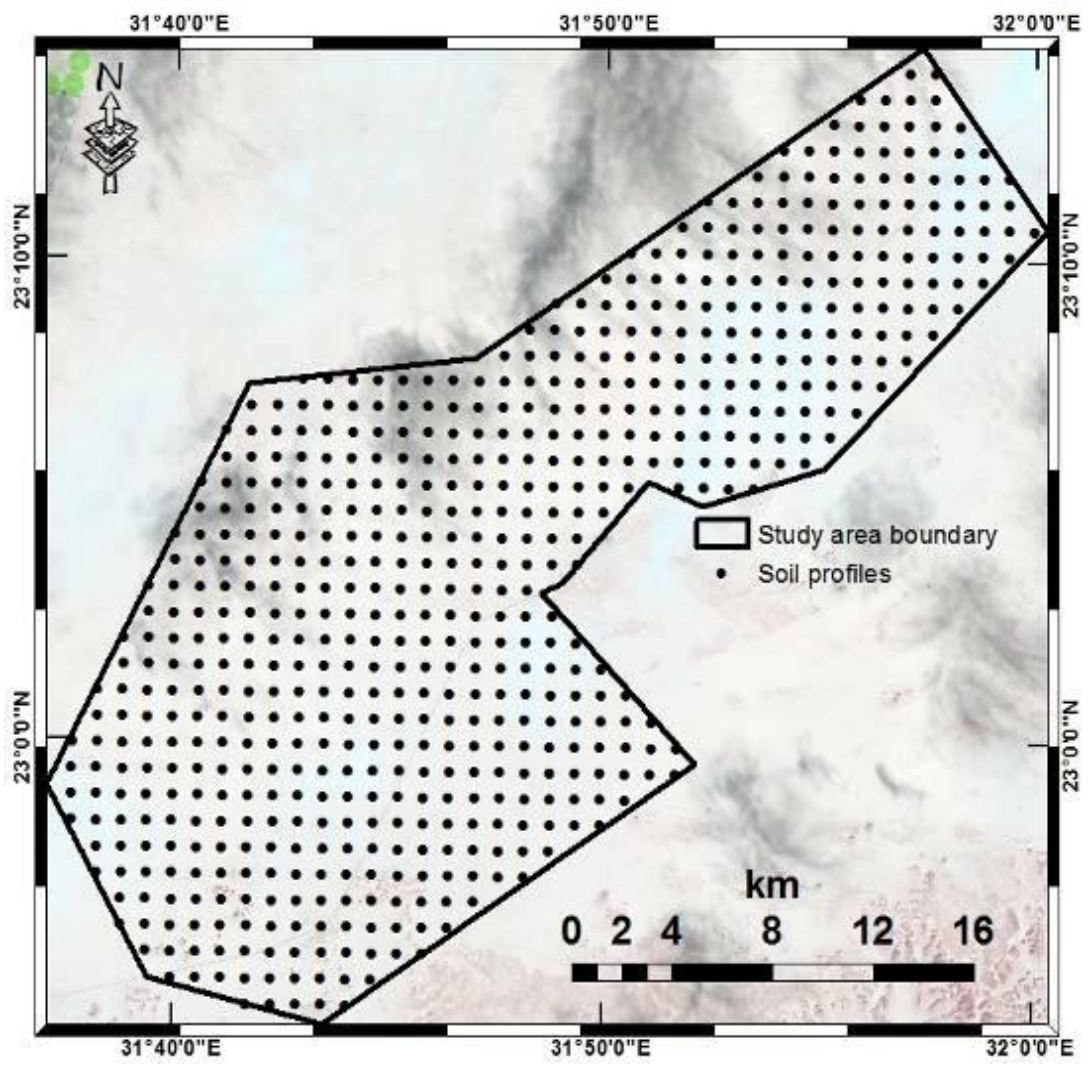

Figure 4. Soil profile covering the study area

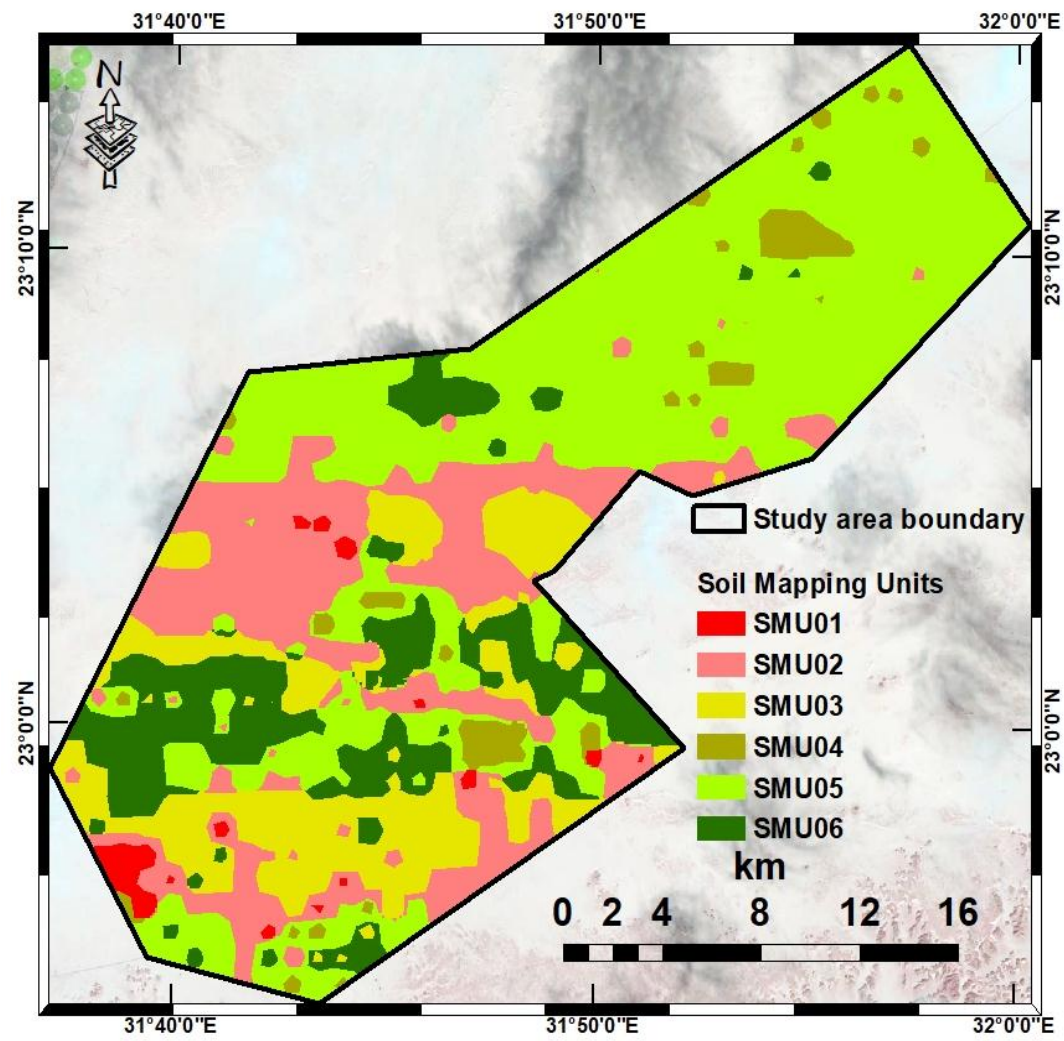

Figure 5. Soil mapping units in the study area 
Table 4. Descriptive Statistics of some soil properties of soil mapping units

\begin{tabular}{|c|c|c|c|c|c|c|c|c|c|}
\hline \multirow{2}{*}{$\begin{array}{c}\text { Statistical } \\
\text { Parameters }\end{array}$} & \multicolumn{9}{|c|}{ SMU01 - Shallow coarse-textured soils ( 1820.09 faddan) } \\
\hline & Depth & Gravel & slope & clay & silt & sand & $\mathrm{CaCO}_{3}$ & EC & pH \\
\hline Mean & 25.29 & 17.30 & 0.51 & 6.05 & 9.41 & 84.54 & 6.72 & 1.86 & 7.87 \\
\hline St. Error & 3.80 & 2.87 & 0.08 & 0.86 & 1.10 & 1.18 & 1.29 & 0.38 & 0.05 \\
\hline St. Deviation & 15.66 & 11.82 & 0.34 & 3.53 & 4.52 & 4.88 & 5.31 & 1.56 & 0.19 \\
\hline Variance & 245.22 & 139.73 & 0.11 & 12.48 & 20.40 & 23.78 & 28.21 & 2.42 & 0.04 \\
\hline Kurtosis & -1.61 & 0.45 & -0.53 & -0.68 & 0.68 & 5.51 & 3.38 & 5.23 & 2.88 \\
\hline Skewness & -0.24 & 0.59 & 0.87 & -0.60 & 0.44 & 2.09 & 1.88 & 2.19 & -1.22 \\
\hline Minimum & 5.00 & 0.14 & 0.13 & 0.09 & 0.18 & 77.86 & 0.31 & 0.61 & 7.34 \\
\hline Maximum & 45.00 & 44.94 & 1.19 & 11.34 & 18.00 & 99.67 & 20.78 & 6.67 & 8.16 \\
\hline \multirow[t]{2}{*}{ Count } & 17 & 17 & 17 & 17 & 17 & 17 & 17 & 17 & 17 \\
\hline & \multicolumn{9}{|c|}{ SMU02 - Shallow Moderately coarse-textured soils (30276.13 faddan) } \\
\hline Mean & 19.87 & 10.61 & 0.34 & 9.46 & 18.80 & 71.73 & 6.40 & 1.25 & 7.97 \\
\hline St. Error & 2.19 & 1.19 & 0.03 & 0.43 & 0.74 & 0.76 & 0.49 & 0.13 & 0.04 \\
\hline St. Deviation & 13.69 & 7.42 & 0.19 & 2.70 & 4.61 & 4.77 & 3.05 & 0.84 & 0.24 \\
\hline Variance & 187.48 & 55.12 & 0.03 & 7.28 & 21.25 & 22.77 & 9.29 & 0.71 & 0.06 \\
\hline Kurtosis & -1.48 & -0.50 & 3.59 & 2.96 & 2.27 & 5.96 & 4.17 & 2.40 & 1.55 \\
\hline Skewness & 0.12 & 0.34 & 1.73 & 0.64 & -0.07 & -1.98 & 1.96 & 1.72 & 0.05 \\
\hline Minimum & 5.00 & 0.00 & 0.12 & 1.56 & 5.93 & 55.27 & 1.32 & 0.44 & 7.41 \\
\hline Maximum & 45.00 & 29.04 & 0.98 & 16.67 & 29.50 & 79.76 & 15.89 & 3.86 & 8.62 \\
\hline \multirow[t]{2}{*}{ Count } & 39 & 39 & 39 & 39 & 39 & 39 & 39 & 39 & 39 \\
\hline & \multicolumn{9}{|c|}{ SMU03 - Moderately deep coarse-textured soils (22169.92 faddan) } \\
\hline Mean & 82.38 & 15.92 & 0.35 & 3.66 & 13.86 & 82.48 & 8.16 & 2.21 & 8.06 \\
\hline St. Error & 1.50 & 0.91 & 0.02 & 0.28 & 0.54 & 0.39 & 0.80 & 0.21 & 0.03 \\
\hline St. Deviation & 17.05 & 10.38 & 0.20 & 3.17 & 6.12 & 4.48 & 9.12 & 2.40 & 0.32 \\
\hline Variance & 290.78 & 107.69 & 0.04 & 10.06 & 37.47 & 20.09 & 83.23 & 5.74 & 0.10 \\
\hline Kurtosis & -1.13 & 1.00 & 3.23 & -0.68 & -0.62 & -0.10 & 52.50 & 10.92 & 3.70 \\
\hline Skewness & -0.47 & 1.11 & 1.50 & 0.54 & 0.37 & -0.52 & 6.21 & 2.94 & 0.78 \\
\hline Minimum & 50.00 & 0.52 & 0.04 & 0.01 & 4.24 & 71.00 & 0.27 & 0.20 & 7.41 \\
\hline Maximum & 100.00 & 52.72 & 1.22 & 12.07 & 28.49 & 93.78 & 90.77 & 16.14 & 9.65 \\
\hline \multirow[t]{2}{*}{ Count } & 130 & 130 & 130 & 130 & 130 & 130 & 130 & 130 & 130 \\
\hline & \multicolumn{9}{|c|}{ SMU04 - Moderately deep moderately coarse-textured soils (5009.89 faddan) } \\
\hline Mean & 85.98 & 9.32 & 0.37 & 10.13 & 18.48 & 71.39 & 5.79 & 1.41 & 8.16 \\
\hline St. Error & 0.99 & 0.58 & 0.01 & 0.20 & 0.31 & 0.37 & 0.18 & 0.10 & 0.02 \\
\hline St. Deviation & 15.65 & 9.19 & 0.21 & 3.14 & 4.90 & 5.90 & 2.78 & 1.62 & 0.39 \\
\hline Variance & 244.88 & 84.50 & 0.04 & 9.84 & 23.97 & 34.78 & 7.70 & 2.63 & 0.15 \\
\hline Kurtosis & -0.25 & 9.93 & 5.27 & 1.47 & 1.58 & 2.42 & 17.08 & 18.03 & 2.87 \\
\hline Skewness & -0.95 & 2.59 & 1.58 & 0.41 & 0.75 & -1.71 & 3.03 & 3.86 & 1.39 \\
\hline Minimum & 50.00 & 0.00 & 0.02 & 0.04 & 5.76 & 52.13 & 1.10 & 0.19 & 7.36 \\
\hline Maximum & 100.00 & 63.66 & 1.57 & 19.16 & 35.66 & 80.95 & 26.39 & 11.64 & 9.69 \\
\hline \multirow[t]{2}{*}{ Count } & 248 & 248 & 248 & 248 & 248 & 248 & 248 & 248 & 248 \\
\hline & \multicolumn{9}{|c|}{ SMU05 - Deep coarse-textured soils (68492.63 faddan) } \\
\hline Mean & 124.74 & 19.22 & 0.41 & 5.60 & 10.66 & 83.74 & 4.96 & 1.67 & 7.94 \\
\hline St. Error & 1.77 & 1.10 & 0.03 & 0.30 & 0.57 & 0.41 & 0.41 & 0.32 & 0.03 \\
\hline St. Deviation & 17.55 & 10.88 & 0.26 & 3.02 & 5.64 & 4.10 & 4.07 & 3.20 & 0.25 \\
\hline Variance & 307.92 & 118.34 & 0.07 & 9.09 & 31.82 & 16.80 & 16.55 & 10.23 & 0.06 \\
\hline Kurtosis & -1.18 & -0.16 & 3.05 & -0.71 & 0.33 & 0.18 & 3.26 & 71.09 & -0.30 \\
\hline Skewness & 0.09 & 0.76 & 1.53 & -0.25 & 1.11 & -0.67 & 1.77 & 8.03 & 0.24 \\
\hline Minimum & 100.00 & 2.63 & 0.03 & 0.01 & 4.13 & 73.15 & 0.19 & 0.23 & 7.39 \\
\hline Maximum & 150.00 & 48.25 & 1.38 & 11.36 & 26.35 & 92.45 & 20.27 & 30.61 & 8.62 \\
\hline Count & 98 & 98 & 98 & 98 & 98 & 98 & 98 & 98 & 98 \\
\hline
\end{tabular}




\section{Continue.Table 4}

\begin{tabular}{ccccccccccc}
\multicolumn{10}{c}{ SMU06 - Deep moderately coarse-texture soils (20551.33 faddan) } \\
\hline Mean & 128.74 & 15.06 & 0.38 & 10.36 & 19.39 & 70.25 & 4.08 & 1.26 & 7.96 \\
Standard Error & 1.81 & 1.08 & 0.02 & 0.38 & 0.60 & 0.71 & 0.37 & 0.08 & 0.03 \\
St. Deviation & 16.80 & 10.02 & 0.21 & 3.48 & 5.53 & 6.56 & 3.42 & 0.71 & 0.25 \\
Variance & 282.21 & 100.43 & 0.04 & 12.10 & 30.53 & 43.08 & 11.73 & 0.50 & 0.06 \\
Kurtosis & -1.29 & -0.31 & 1.64 & 0.96 & 0.01 & 0.52 & 9.46 & 8.42 & 1.28 \\
Skewness & -0.04 & 0.73 & 1.33 & 0.26 & 0.44 & -1.14 & 2.87 & 2.34 & 0.59 \\
Minimum & 100.01 & 2.60 & 0.05 & 1.07 & 8.84 & 52.01 & 0.85 & 0.22 & 7.39 \\
Maximum & 149.99 & 43.88 & 1.00 & 19.95 & 33.32 & 78.96 & 20.96 & 4.48 & 8.86 \\
Count & 86 & 86 & 86 & 86 & 86 & 86 & 86 & 86 & 86 \\
\hline
\end{tabular}

carbonate content ranges from 1.32 to $15.89 \%$, non saline to very slightly saline $(0.44$ to $3.86 \mathrm{dS} / \mathrm{m})$ and slightly to strongly alkaline (7.41-8.62). According to the values of standard deviation and standard error, soils showed that the soil depth has the highest values, while the surface slope followed by $\mathrm{pH}$ have the lowest ones, respectively. Applying the mean valuees of the different soil properties indicated that the soils are "Flat, shallow, Moderately coarse- textured, Moderately calcareous, Non-saline, Moderately alkaline",

\section{3- Moderately deep coarse-textured soils (SMU03)}

This unit covers an area of about 22169.92 faddan, soils of which are either sandy or loamy sand with gravel content ranging from 0.52 to $52.72 \%$. The surface attined flat to almost flat slope (0.04 to $1.22 \%)$. Similarly, soils vary from slightly calacreous to extremely calcareous $(0.27-90.77 \%$ as total carbonate content). The soil salinity is non-saline to strongly saline ( 0.20 to $16.14 \mathrm{dS} / \mathrm{m}$ ) and slightly to very strongly alkaline where $\mathrm{pH}$ valued rnage from 7.41 to 9.65 . With respect to the standard deviation and standard error, as the pervious unit, the soil depth has the highest values of while the surface slope and $\mathrm{pH}$ have gotten the the lowest values, rsepectively. By the mean values the studied paramters, the soils under consideration could be define as "Flat, Moderately deep, Gravelly coarsetextured, Moderately calcareous, Very slightly saline, Moderately alkaline soils".

\section{4- Moderately deep moderately coarse-textured soils (SMU04)}

The soils, encompassing around 5009.98 faddan, have sandy loam texture and the gravel content ranges from 0 to $63.66 \%$. The soil surface has a flat to almost falt slope and the soils are slightly to extermely calcareous (1.10-26.39). These soils are non-saline to moderately saline (0.19-11.64), and slightly alkaline to very strongly alkaline with $\mathrm{pH}$ values ranges from 7.36 to 9.69. As described in the previous unit, the soil depth has the highest values of standard deviation and standard error while surface slope and soil $\mathrm{pH}$ have the lowest values. The mean values of the determined soils parameters showed that these soils are "Flat,
Moderately deep, Moderately coarse-textured,

Moderately calcareous, Non-saline, Moderately alkaline".

\section{5- Deep coarse-textured soils (SMU05)}

This soil mapping unit covers an area of about 68492.63 faddan represented by sand and/or loamy sand with gravel content ranged from 2.63 to $48.25 \%$. The surface slope ranges from 0.03 to $1.38 \%$. These soils could be described as slightly to extermely calcareous where calcium carbonate content ranges from 0.19 to $20.27 \%$, on the other hand, the soil salinity and $\mathrm{pH}$ respectively are non-saline to strongly saline $(0.23$ to $30.61 \mathrm{dS} / \mathrm{m}$ ) and slightly to strongly alkaline $(7.39$ to 8.62). Similar to the overmentioned, the soil depth and surface slope and $\mathrm{pH}$ have the highest and the lowest standard deviation and standard error values. The studied soils detected in this unit are related to Flat, Deep, Gravelly coarse-textured, Moderately calcareous, non-saline, Moderately alkaline.

\section{6- Deep moderately coarse-textured soils (SMU06)}

This unit encompasses an area of about 20369 faddan. The soils of this mapping unit have sandy loam texture with gravels ranged from 2.60 to $43.88 \%$. This units has flat to almost flat $(0.5-1.00 \%)$ derived from surface slope. They are slightly calcareous to strongly calcareous as ranging from 0.85 to $20.96 \%$. The soil salinity, defined by EC values that ranges from 0.22 to $4.48 \mathrm{dS} / \mathrm{m}$, is non-saline to slightly saline. The soil reaction indicated by $\mathrm{pH}$ values ranging from 7.39 to 8.86 is slightly to strongly alkaline. As mentioned in the unit before, the soil depth had the highest values of the standard deviation and standard error, reversely the surface slope and $\mathrm{pH}$ have gotten the lowest values, respectively. According to the mean values of soil properties, the soils are "Deep, Gravelly moderately coarse-textured, Moderately calcareous, Non-saline, Moderately alkaline.

\section{2- Study area data layers}

The step followed in order to prepare land suitability maps was proceed from deciding what land to develop and when and how to develop. Accordingly the land suitability includes physical characteristics and 
constrains (Bandyopadhyay et al., 2009). In this study the suitability potential analysis attempted to be viewed as a prioritization of land for agricultural development. Therefore, multi-disciplinary study such as filed survey, ground truth, and remotely sensing has been undertaken to carry the potential land suitability to identify the areas to be used for agricultural purpose. In the study under consideration, the parameters used to determine the priority map were put in the order of the most important according to the study area circumstances and they are shown previously in Table (2) and were mapped to get the spatial variability of each property' severity as soil depth (Figure. 6), soil texture (Figure 7), soil gravel (Figure 8), surface slope (Figure 9), calcium carbonate (Figure 10), soil salinity (Figure 11) and pH (Figure 12)

Table 5. The limitation of soil properties represented by feddan and percentages

\begin{tabular}{|c|c|c|c|}
\hline Soil properties & Limitation & Area/ faddan & Percentage \\
\hline \multirow[t]{5}{*}{ Soil depth (SD) } & Sever & 5876 & 3.77 \\
\hline & Moderate & 12203 & 8.07 \\
\hline & Slight & 92731 & 62.87 \\
\hline & No & 37509 & 25.29 \\
\hline & Total & 148320 & 100 \\
\hline \multirow[t]{5}{*}{ Soil Texture (ST) } & Sever & 3984 & 2.48 \\
\hline & Moderate & 16544 & 11.03 \\
\hline & Slight & 49952 & 33.76 \\
\hline & No & 77840 & 52.73 \\
\hline & Total & 148320 & 100 \\
\hline \multirow[t]{5}{*}{ Soil gravel (SG) } & Sever & 1091 & 0.51 \\
\hline & Moderate & 44887 & 30.31 \\
\hline & Slight & 69295 & 46.92 \\
\hline & No & 33047 & 22.26 \\
\hline & Total & 148320 & 100 \\
\hline \multirow[t]{3}{*}{ Soil slope (SL) } & Slight & 3045 & 1.61 \\
\hline & No & 145275 & 98.39 \\
\hline & Total & 148320 & 100 \\
\hline \multirow[t]{5}{*}{ Soil calcium Carbonate (SC) } & Sever & 391 & 0.04 \\
\hline & Moderate & 9770 & 6.42 \\
\hline & Slight & 14420 & 9.58 \\
\hline & No & 123739 & 83.96 \\
\hline & Total & 148320 & 100 \\
\hline \multirow[t]{5}{*}{ Soil Salinity (SS) } & Sever & 1328 & 0.67 \\
\hline & Moderate & 6225 & 4.01 \\
\hline & Slight & 20973 & 14.04 \\
\hline & No & 119794 & 81.28 \\
\hline & Total & 148320 & 100 \\
\hline \multirow[t]{5}{*}{ Soil Reaction (SR) } & Sever & 1931 & 1.09 \\
\hline & Moderate & 10553 & 6.95 \\
\hline & Slight & 72314 & 48.97 \\
\hline & No & 63522 & 42.99 \\
\hline & Total & 148320 & 100 \\
\hline
\end{tabular}




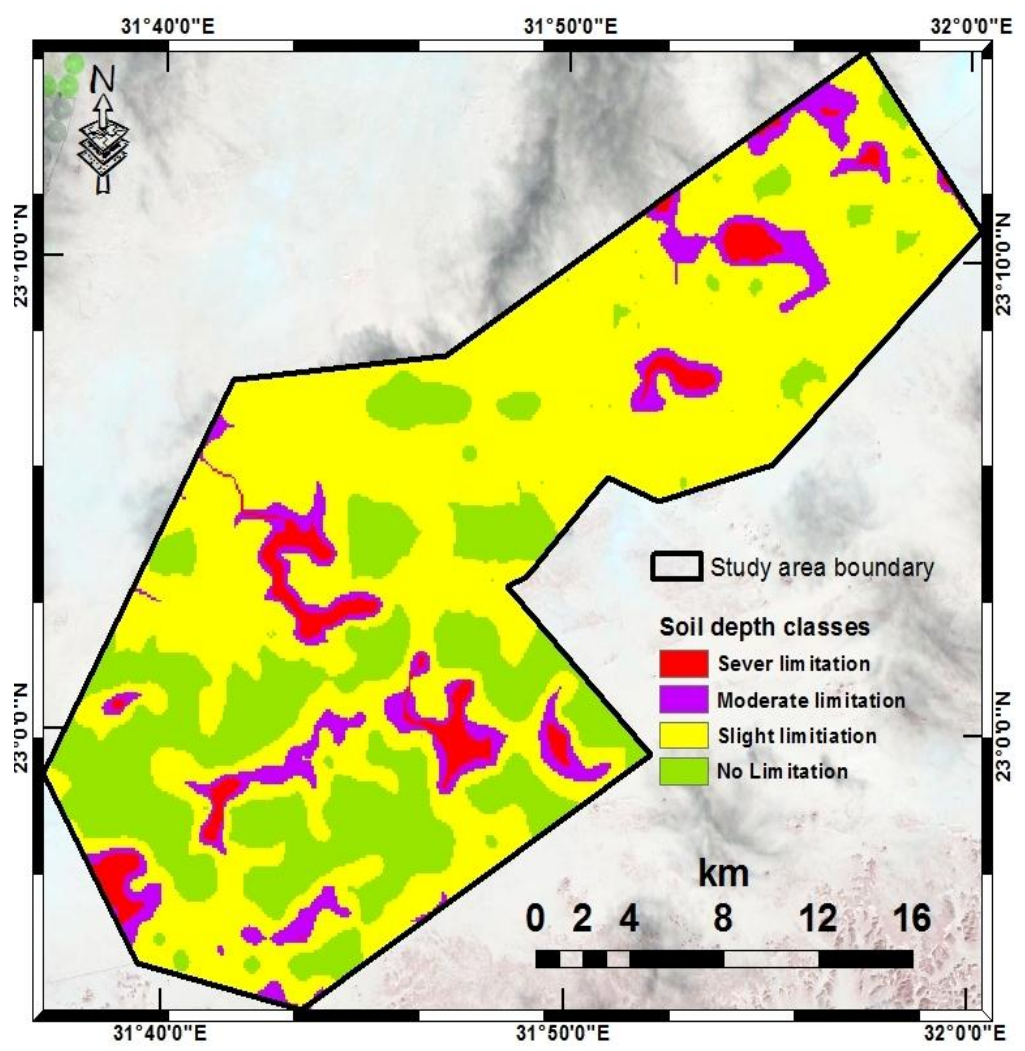

Figure6.Variability map of soil depth severity

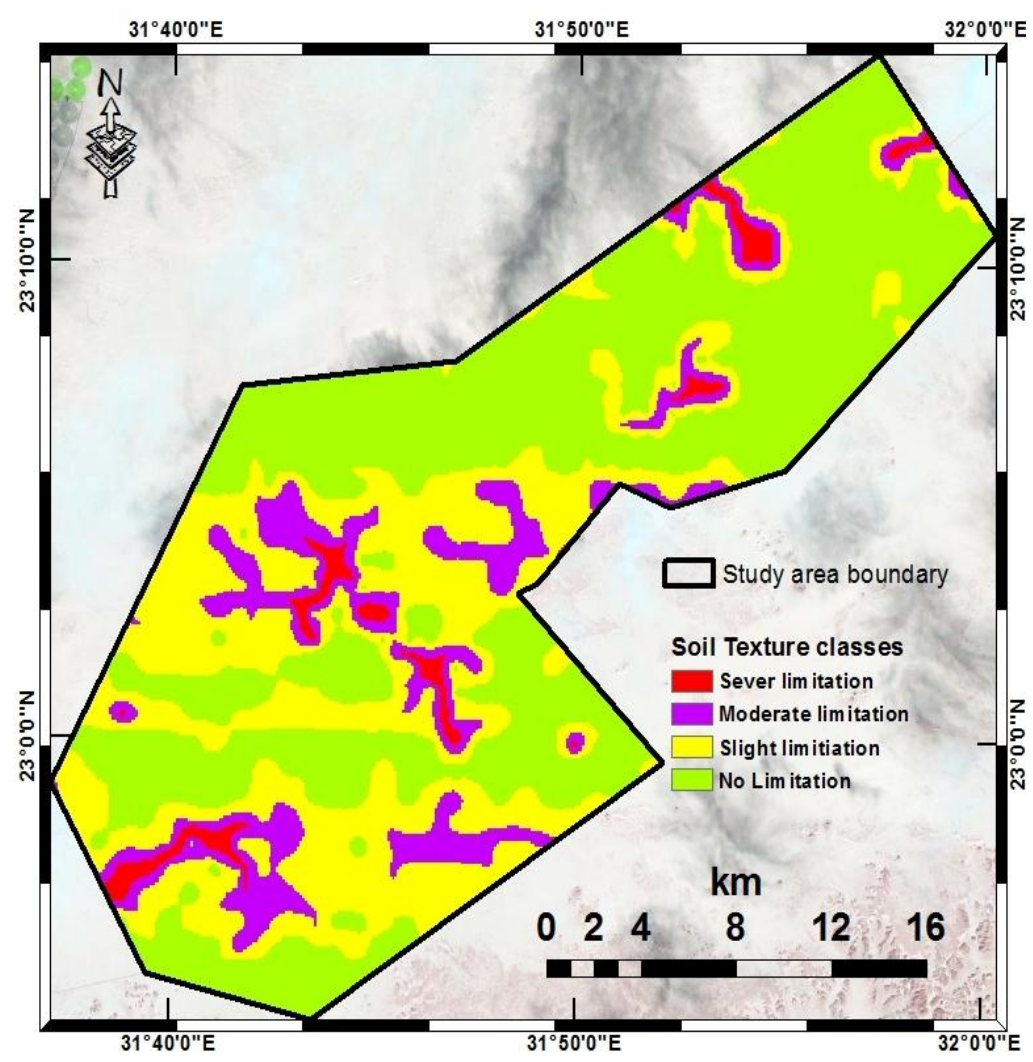

Figure7.Variability map of soil texture severity 


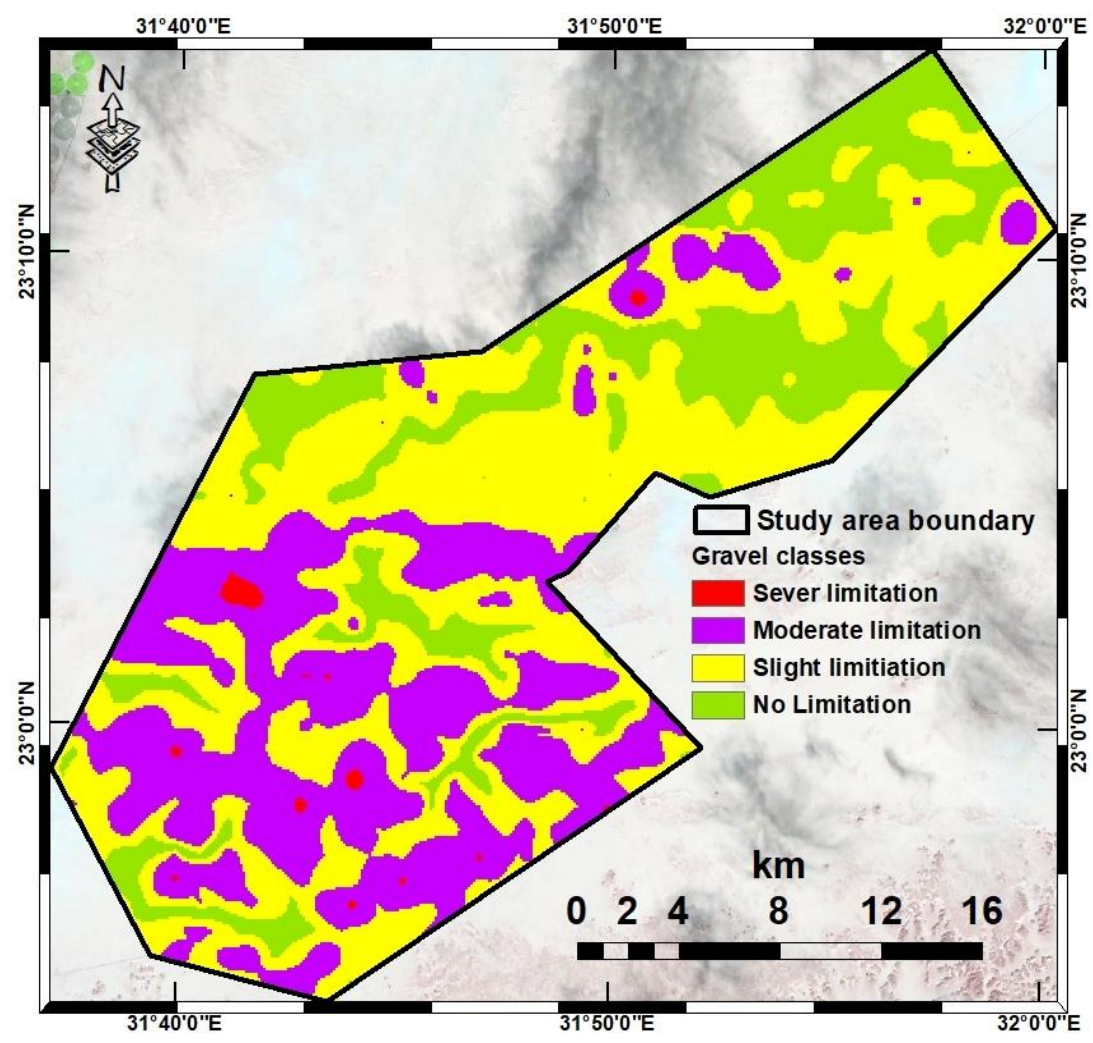

Figure 8.Variability map of soil gravels severity

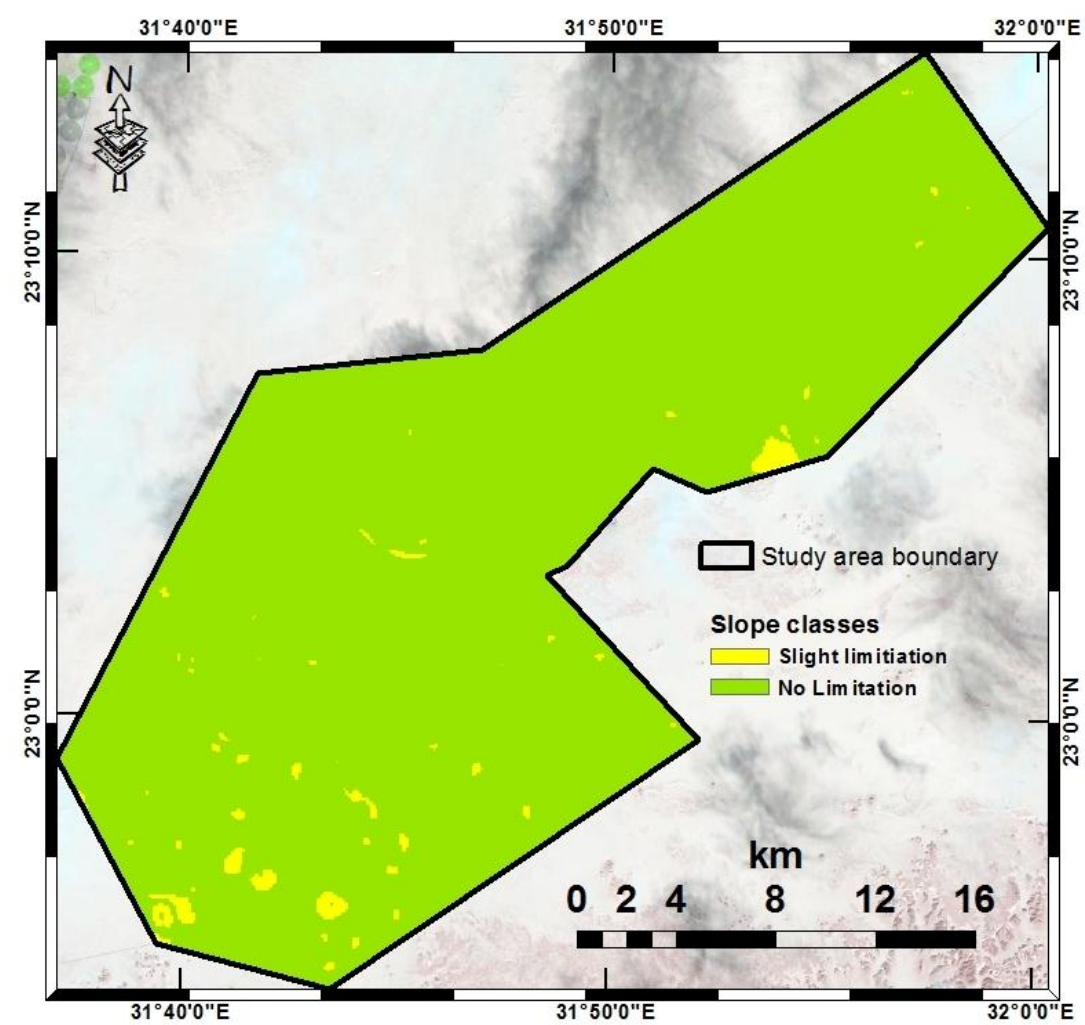

Figure9.Variability map of soil surface slope severity 


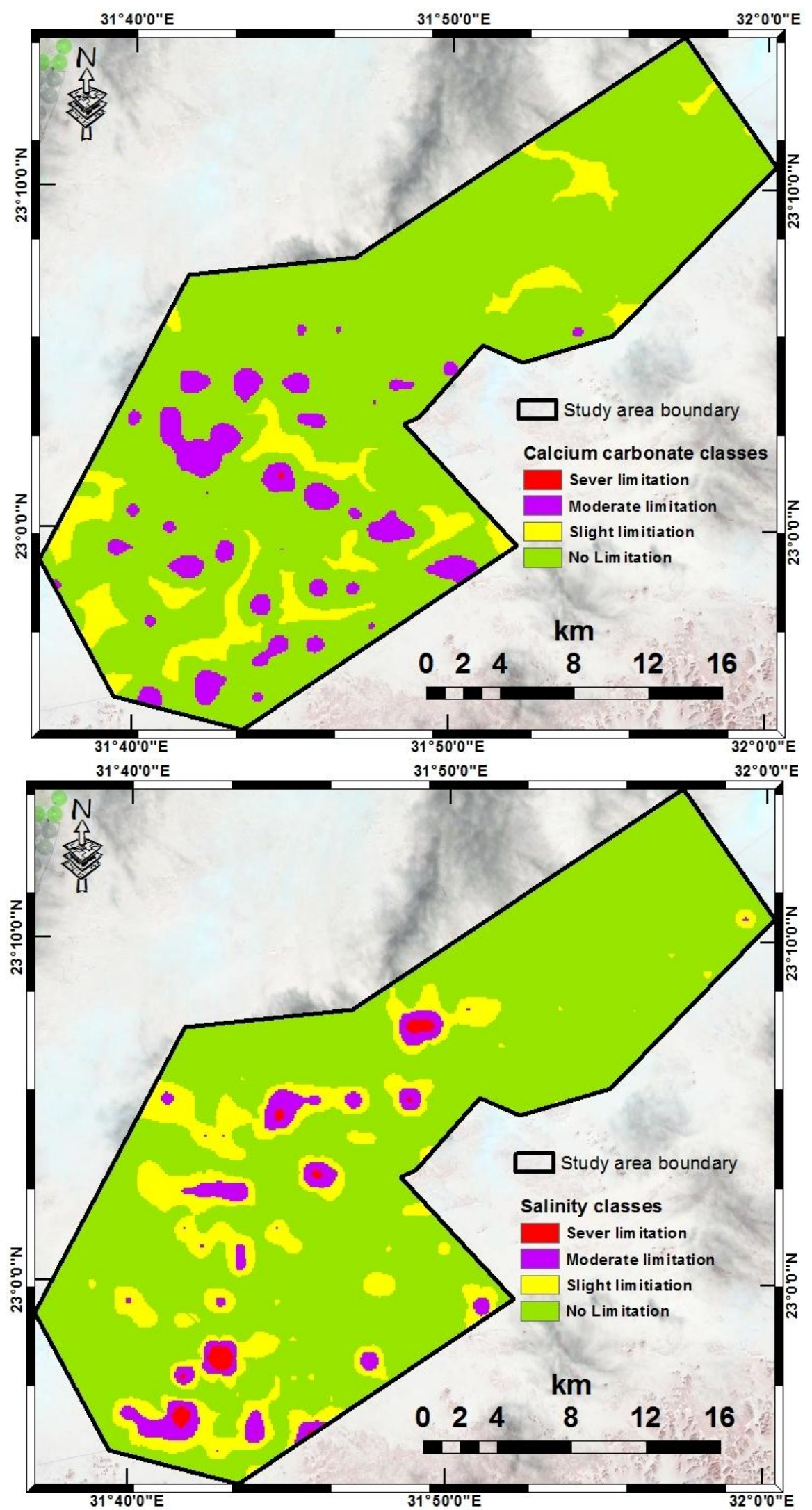

Figure11.Variability map of soil surface slope severity 


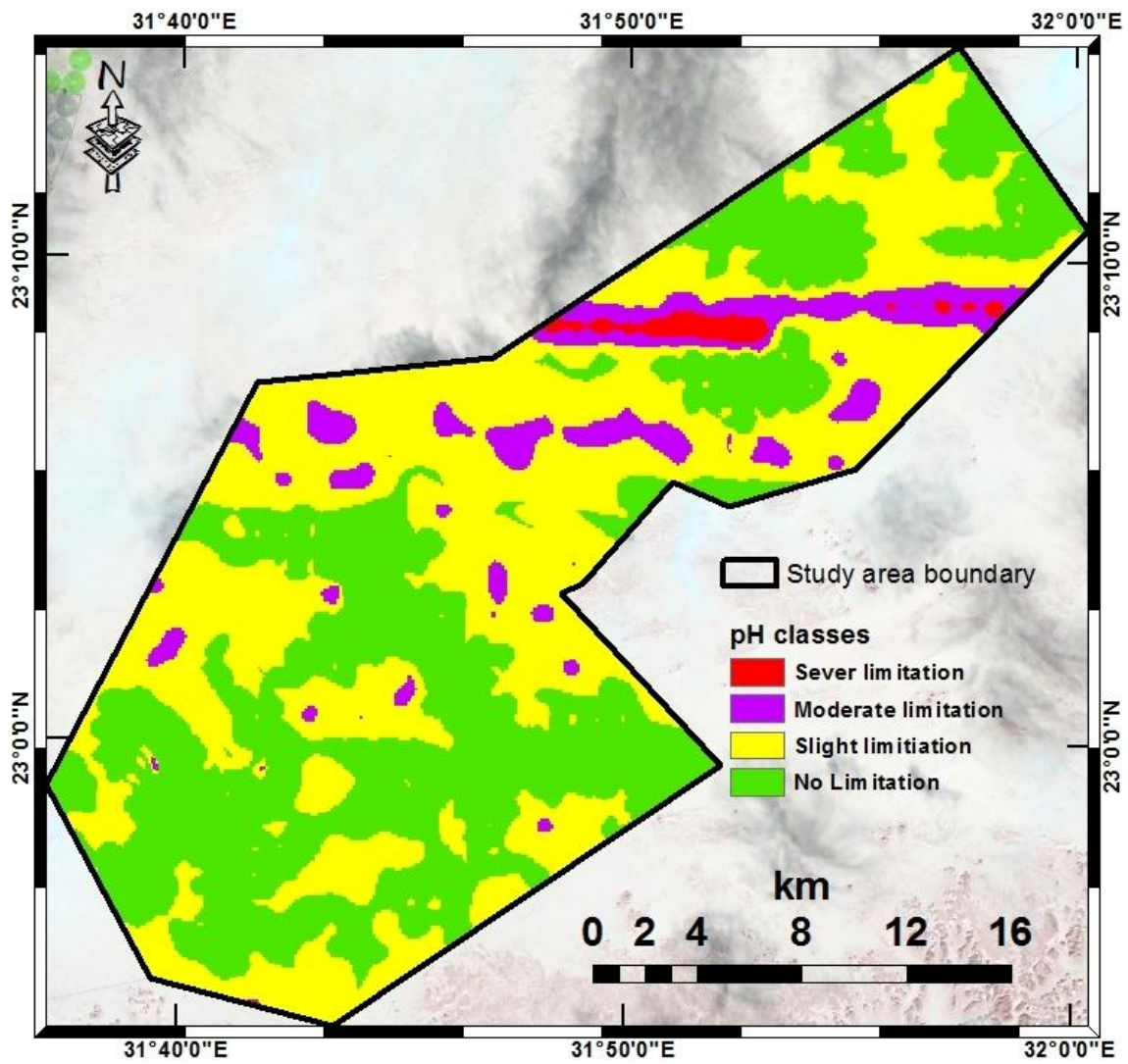

Figure 12. Variability map of soil pH severity

The thematic layers resulted from interpolation process were reclassified according to the limitation to reflect the importance or of each soil property and its effect on the potential land use as the current study. Showing the limitation that reflect the importance of each property in figures or numbers is a good and clear way for the interpretation of any phenomena. So, Table (5) present the area by feddan for each soil property based on its limitation. It is clear that the slight limitation category of soil depth (SD), soil gravel (SG) and soil reaction (SR) have gotton the wider area followed by "No limitation" except the soil gravel representing moderate limitation is the following order. On contrast, the "No limitation" of soil texture (ST), soil slope (SL), soil carbonate (SC), and soil salinity (SS) has the wider area followed by the slight limitation.

\section{3- The Agricultural Potentiality Model}

After categorization, all the created thematic layers by using interpolation method were incorporated with each other in GIS environment by using the weighted overlay method using ArcGIS10.4.1 Figure (13). From the combined layers, Land Suitability Potential Index (LSPI) was delineated for agrarian purposes by gathering the classes into different suitability zones: not suitable, marginal suitable, moderately suitable, and highly suitable as shown in Table (6). Accordingly, the moderately suitable class covers the largest area (120205 feddan) representing about $81.04 \%$ followed by the highly suitable class (13686 feddan) representing about $9.23 \%$ and marginal suitable (13358 feddan) representing about $9.01 \%$, while the not suitable class recorded the lowest coverage area (1071feddan) by about $0.72 \%$. By suing the above mentioned model, the agriculturally-based land potential map was created and it is shown in Figure (14). The analysis shows that the study area is moderately suitable, Where, the soil depth, soil gravel, and soil reaction were the major limitation comparing with the other soil factors. 


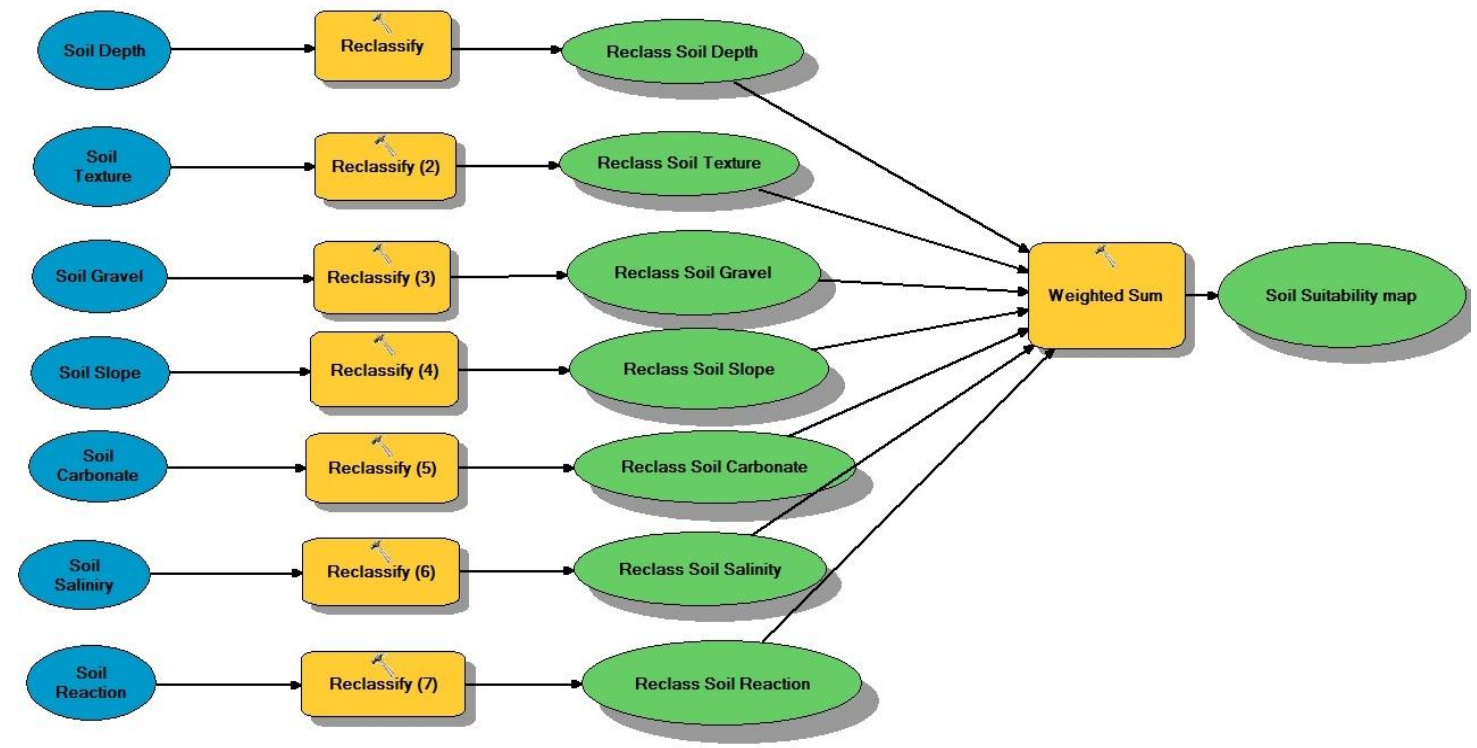

Figure 13. Schematic methodology of land suitability analysis in ArcGIS Modelbuilder

Table 6. The final agricultural potentiality and their covering area and percentage

\begin{tabular}{ccc}
\hline classes & Area/ faddan & Percentage \\
\hline Not suitable & 1071 & 0.72 \\
Marginal suitable & 13358 & 9.01 \\
Moderately suitable & 120205 & 81.04 \\
Highly suitable & 13686 & 9.23 \\
Total & 148320 & 100 \\
\hline
\end{tabular}

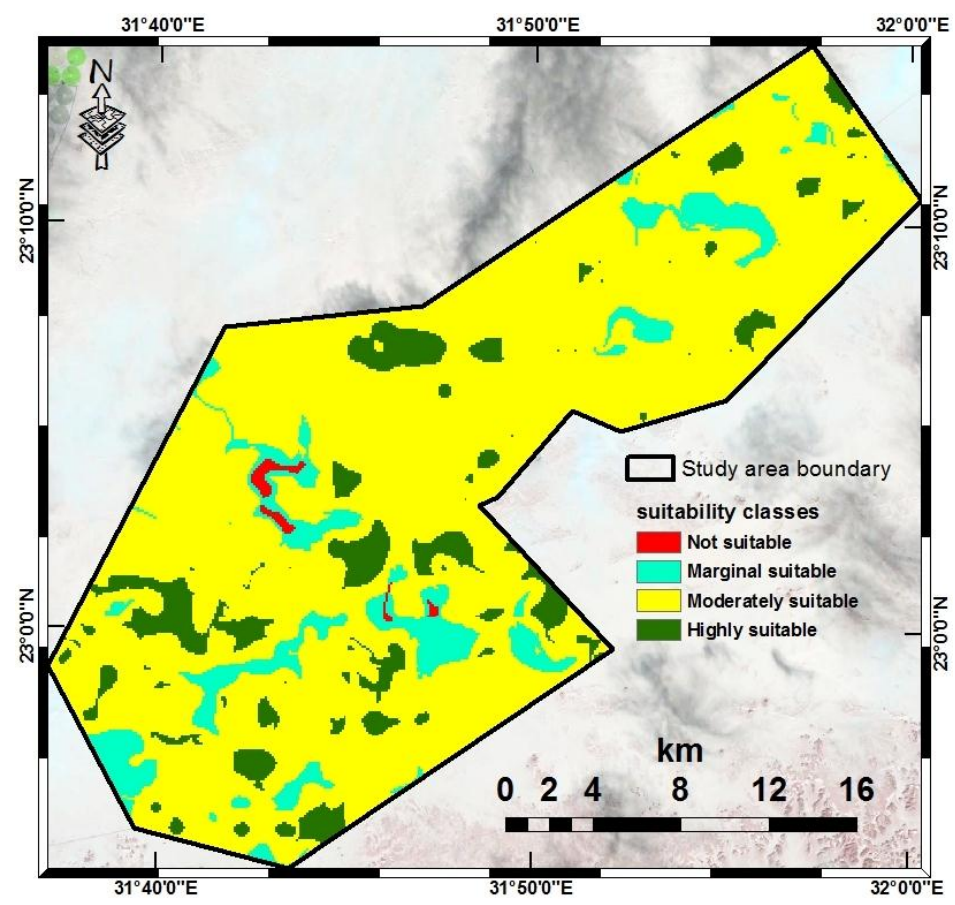

Figure 14.The agricultural potentiality map of the study area 


\section{CONCLUSION}

From the overmentioned information, estimating the land evaluation potentiality is one of the most important steps in agricultural planning. When the irrigation water is available, studying the soil characteristics, especially the most limiting factors, in detail plays a vital role in agricultural expansion. Geographical information system (GIS) provides the possibility to interpolate each soil parameter in order to assess its spatial variability. Therefore, it determines the most promising area that could be created from interpreting soil quality classes as sever, moderate, slight, or no limitation. By using the Modelbuilder toolset of GIS programme, the spatial variability of the studied soil parameters could be overlaid together to evaluate the land suitability potential based on the weight of each parameters according to the study area circumstances.

In the current study, the Land Suitability Potential Index was clearly computed as LSPI $=0.6(\mathrm{SD})+0.2$ $(\mathrm{ST})+0.15(\mathrm{SG})+0.02(\mathrm{SL})+0.01(\mathrm{SC})+0.01(\mathrm{SS})+$ 0.1 (SR), where SD is soil depth, ST is soil texture, SL soil slope, SG is soil gravel, SC soil carbonate, SS is soil salinity, and SR is soil reaction. Accordingly the soil of study area is moderately suitable representing about $81.04 \%$ of the total area, where the soil depth, soil gravel, and soil reaction were the major soil limitation.

\section{REFERENCES}

Baja, S., D. M.Chapman, and D. Dragovich. 2002. A conceptual model for defining and assessing land management units using a fuzzy modeling approach in GIS environment. Environmental management 29: 647661.

Bandyopadhyay, S., R. Jaiswal, V. Hegde, and V. Jayaraman. 2009. Assessment of land suitability potentials for agriculture using a remote sensing and GIS based approach. International Journal of Remote Sensing 30: 879-895.

Bodaghabadi, M. B., J.Martínez-Casasnovas, P. Khakili, M. Masihabadi, and A. Gandomkar. 2015. Assessment of the FAO traditional land evaluation methods, A case study: Iranian Land Classification method. Soil Use and Management 3:384-396.

Bouyoucos, G. J. 1962. Hydrometer method improved for making particle size analyses of soils. Agronomy journal 54: 464-465.

Brink, R., and A.Young. 1977. "A framework for land evaluation." ILRI.

Chen, J. 2014. GIS-based multi-criteria analysis for land use suitability assessment in City of Regina. Environmental Systems Research 3.13.

De la Rosa, D., F.Mayol, E. Diaz-Pereira, M.Fernandez, and D.Rosa Jr. 2004. A land evaluation decision support system (MicroLEIS DSS) for agricultural soil protection: with special reference to the Mediterranean region. Environmental Modelling \& Software 19: 929-942.

De la Rosa, D., J. Moreno, L.Garcia, and J.Almorza. 1992. MicroLEIS: A microcomputer-based Mediterranean land evaluation information system. Soil Use and Management 8: 89-96.

De la Rosa, D., and Van Diepen, C. 2002. Qualitative and Quantitative Land Evaluations.

DRC (2014). Integrated Agriculture Development of Toshka District. DRC Staff Annual report. Desert Research Center publications.

El Baroudy, A. A. 2016. Mapping and evaluating land suitability using a GIS-based model. Catena 140, 96-104.

Guo, X., Wang, J., Xie, J., He, T., Lian, G., and Lv, C. 2005. Land degradation analysis based on the land use changes and land degradation evaluation in the Huan Beijing area. In "Remote Sensing for Environmental Monitoring, GIS Applications, and Geology V", Vol. 5983, pp. 598319. International Society for Optics and Photonics.

Halder, J. C. 2013. Land suitability assessment for crop cultivation by using remote sensing and GIS. Journal of geography and Geology 5, 65.

Hamad, A.I .2016. The Use of Inverse Distance Weighted and Fuzzy Logic to Estimate Land Suitability by Geographic Information System in South of Iraq. Alex. Sci . Exch. J. 37: $26-35$.

Hamza, W., and Mason, S. 2004. Water availability and food security challenges in Egypt. In Proceedings International Forum on Food Security Under Water Scarcity in the Middle East: Problems and Solutions. Como. Italy. pp: 24-27.

Hamzeh, S., Mokarram, M., and Alavipanah, S. K. 2014. Combination of Fuzzy and AHP methods to assess land suitability for barley: Case Study of semi arid lands in the southwest of Iran. Desert 19: 173-181.

Jahn, R., Blume, H., Asio, V., Spaargaren, O., and Schad, P. 2006. Guidelines for soil description, FAO.

Kalogirou, S. 2002. Expert systems and GIS: an application of land suitability evaluation. Computers, environment and urban systems 26:89-112.

Kerr, J. M., Pangare, G., and Pangare, V. 2002. "Watershed development projects in India: an evaluation," Intl Food Policy Res Inst.

Middleton, N. J., and Thomas, D. S. 1992. World atlas of desertification.

Mokarram, M., Rangzan, K., Moezzi, A., and Baninemeh, J. 2010. Land suitability evaluation for wheat cultivation by fuzzy theory approache as compared with parametric method. Proceedings of the international archives of the photogrametry, remote sensing and spatial information sciences 38:1440-145. 
Moneim, A. A. A., Zaki, S., and Diab, M. 2014. Groundwater Conditions and the Geoenvironmental Impacts of the Recent Development in the South Eastern Part of the Western Desert of Egypt. Journal of Water Resource and Protection 6.381.

O'Geen, A. T. (2008). A revised storie index for use with digital soils information, UCANR Publications.

Rockström, J., Barron, J., and Fox, P. 2002. Rainwater management for increased productivity among smallholder farmers in drought prone environments. Physics and Chemistry of the Earth, Parts A/B/C 27: 949-959.

Rockström, J., Barron, J., and Fox, P. 2003. Water productivity in rain-fed agriculture: challenges and opportunities for smallholder farmers in drought-prone tropical agroecosystems. Water productivity in agriculture: Limits and opportunities for improvement 85199. 8.

Schoeneberger, P. J. P. J. 2002. Field Book for Describing and Sampling Soils: Version 2.0. National Soil Survey Center, Natural Resources Conservation Service.

Sherrod, L., Dunn, G., Peterson, G., and Kolberg, R. 2002. Inorganic carbon analysis by modified pressure-calcimeter method. Soil Science Society of America Journal 66:299305.

Soil Survey Staff.1993. .Soil survey manual,.United States Department of Agriculture Natural Resources Conservation Service.

Sonmez, S., Buyuktas, D., Okturen, F., and Citak, S. 2008. Assessment of different soil to water ratios (1: 1, 1: 2.5, 1: 5 ) in soil salinity studies. Geoderma 144: 361-369.

Sys, C., and Verheye, W. 1972. Principles of Land Classification in Arid and Semi Arid Regions. State University Ghent.

USDA. 2004. Soil Survey Laboratory Methods Manual: Soil Survey Investigations Report No. 42, Version 4.0, November 2004. United States Department of Agriculture Natural Resources Conservation Service.

Yen, B. T., Pheng, K. S., and Hoanh, C. T. 2006. Land Use Suitability Evaluation Tool User's guide. INTERNATIONAL RICE RESEARCH INSTITUTE DAPO Box 7777 Metro Manila Philippines, 15. 


\section{الملخص العربي}

\section{إمكانات التنمية الزراعية لبعض الأراضي بإمتداد منطقه أسوان - توشكا. \\ عبدالصمد عبدالستار علي الضبع و أسماء عبده شطا و محمد يحيي دراز}

أساس حديتها إلي شديدة الخطورة، ومعتدلة، وطفيفة، وبلا

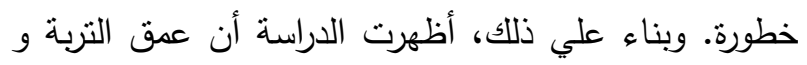
محتوي التربة من الحصي وتفاعل التربة كانت هي أهم المحدات الرئيسية بالمقارنة بعوامل التربة الأخرى. وقد تم

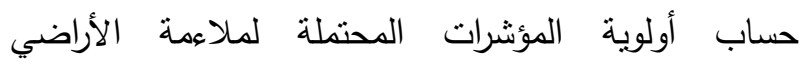
للأغراض الزراعية بمساهمة المعايير المذكورة أعلاه. وقد صنفت الأراضي وفقا للإمكانات إلي غير صالحة، هامشية الصلاحية، متوسطة الصلاحية، و عالية الصلاحية. وقد تحققت هذه الفئات بإجراء النطابق الموضعي للطبقات المختلفة مع ما يقابلها من أوزان في نظام المعلومات الجغرافية (GIS). وأوضحت مخرجات الدراسة ان منطقة الدراسة يمكن وصفها أساسا بأنها متوسطة الصالحية حيث

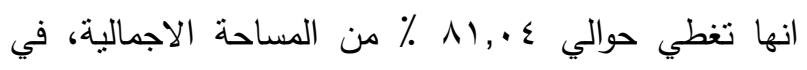
حين أنها عالية الصالحية وهامشية الصالحية وغير صالحة كالهي

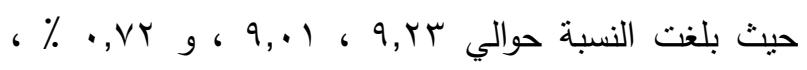
علي التوالي. وخلصت الدراسة إلى انه يمكن تصنيف اي منطقة بعينها في مناطق زراعية محتملة موزعة مكانيا إستتادا إلى خصائص التربة وخصائص التضاريس و من خلاعله رله مساهمة نظم المعلومات الجغرافية.
إن الإدارة الجيدة للموارد الطبيعية المتاحة في مصر

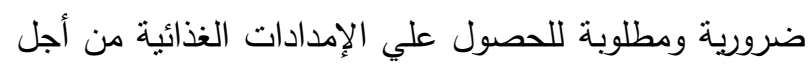
تلبية مطالب الزيادة السريعة في عدد السكان. وعند التجهيز و البدء في تخطيط استخدام الأراضي، يعد تقدير إمكانات الأراضي الزراعية خطوه هامه في المجالات التي تكون فيها الموارد الزراعية محدوده جدا. تعتبر منطقه مفيض توشكي هوري واحده من أكبر المنطاق الواعده للتوسع الزراعي الأفقي حيث تتوفر المياه العذبة. ويتمنل الهدف الرئيسي للاراسة الحالية في وضع خربطة لأولويات الأراضي إستنادا إلى طبقات مواضيعيه مختلفه لبعض مؤشرات التربة التي تؤثز علي الأرئي الإمكانات الزراعية أو تتحكم فيها عن طريق تصميم نموذج مؤنيرات مناسب يستتد إلى نظم المعلومات الجغرافية لتكامل البيانات

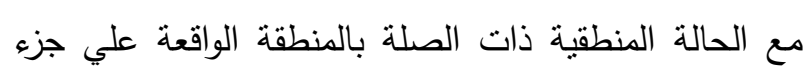
من المنطقة الممتدة من أسوان إلي توشكي. المؤشرات التي

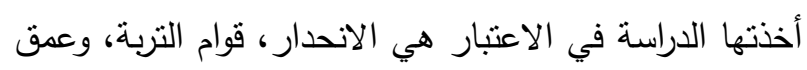

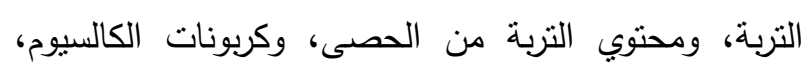

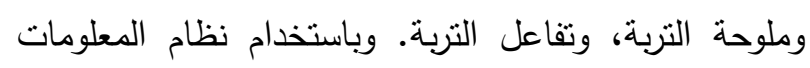
الجغرافية، تم إستيفاء هذه المؤشرات من أجل التعرف علي تتوعها و توزيعها المكاني من خلال تمبيز كل خاصية علي 